\title{
Measuring Customer Feedback, Response and Satisfaction
}

\author{
Rebecca Milner ${ }^{1}$, Adrian Furnham ${ }^{1,2}$ \\ ${ }^{1}$ Research Department of Clinical, Educational and Health Psychology, University College London, London, UK \\ ${ }^{2}$ Norwegian Business School (BI), Olso, Norway \\ Email: a.furnham@ucl.ac.uk
}

How to cite this paper: Milner, R., \& Furnham, A. (2017). Measuring Customer Feedback, Response and Satisfaction. Psychology, 8, 350-362.

https://doi.org/10.4236/psych.2017.83021

Received: December 31, 2016

Accepted: February 11, 2017

Published: February 14, 2017

Copyright (c) 2017 by authors and Scientific Research Publishing Inc. This work is licensed under the Creative Commons Attribution International License (CC BY 4.0).

http://creativecommons.org/licenses/by/4.0/

\begin{abstract}
This paper reviews various different questionnaires designed to measure customer response to a particular service. They differ on various criteria including the dimensions that they are trying to evaluate their established psychometric qualities and their usage. Recommendations for their use are made.
\end{abstract}

\section{Keywords}

Customer Feedback, Questionnaires, Inventories, Service, Quality

\section{Introduction}

Most service organisations are, quite rightly, very interested in measuring the attitudes, beliefs and perceptions of their customers. For some departments (like marketing and sales), it is often one of their primary metrics. As a consequence, various research teams have attempted to devise measures that are comprehensive, reliable and robust. This short paper is a review of the major instruments available to practitioners and researchers.

Customer satisfaction is an assessment of how well a company's products or services meet customer expectations. Customer satisfaction relates to a general and specific psychological evaluation of a customer's experience of a product or service. It is well established that satisfied customers are key to long-term business success (McColl-Kennedy \& Schneider, 2000). The idea of the service-profit chain directly relates customer satisfaction to business success and profitability.

Customer satisfaction predicts customer retention, loyalty, and product repurchase. Customer satisfaction has also been suggested to have an impact on future product search activity, alterations in "hopping behaviour", as well as trials of other available products in the sector. Keiningham and Vavra (2001) found that for every percentage increase in customer satisfaction, there is an average 
increase of $2.37 \%$ of return on investment. Further, when a customer is satisfied they spread this information, acting as marketers for the company.

Gitomer (1998) proposed that nearly one half of American business is built on "word-of-mouth" communication. Such findings demonstrate the importance of customer satisfaction. Whilst some of these ideas and findings are disputed, the measurement of customer reactions remains important. It is thus key to be able to assess these reactions, in order to determine methods of improving business effectiveness.

Measuring customer service is highly important, yet there is no universally accepted measurement scale. There are several theories proposing how we should approach the assessment of customer service. These include the expectancy-disconfirmation approach, the performance-only approach, the technical and functional dichotomy approaches, the service quality vs. service satisfaction approach, and the attribute importance approach. Two of these approaches can be seen in Table 1.

However, measuring customer satisfaction is not simple partly because personal attitudes towards quality vary between individuals. What one may consider to be superior quality may be seen as average by another. Garvin (1984) concludes that "quality lies in the eyes of the beholder" (p. 41). However subjective this may be there is clearly considerable agreement between customers, particularly at extremes of good and bad service.

As assessing quality in service is such a complex task, over the years, service management literature has introduced a number of models to measure overall service quality (Seth, Deshmunkh, \& Vrat, 2005; Senić \& Senić, 2008). The majority of these models are based on comparing what the customer expected from the service or product, and the actual service quality levels perceived. This idea was originally introduced by Grönroos (1982). For instance, the service will be considered excellent if perceptions exceed expectations, but bad if it does not meet expectations (Vázquez et al., 2001).

The aim of this paper is to review the various published measures of customer service.

\section{The Measures}

Three of the most common scales are documented below in Table 2. They seem to be widely used and reported in various academic papers.

Table 1. Two approaches to measurement.

\begin{tabular}{ccc}
\hline Approach & Description & Measure \\
\hline Confirmation-disconfirmation & $\begin{array}{c}\text { Comparing the customer's } \\
\text { expectations vs. what the } \\
\text { customer actually experienced. }\end{array}$ & $\begin{array}{c}\text { The CSI (Customer } \\
\text { Satisfaction Index) }\end{array}$ \\
& $\begin{array}{c}\text { Measuring service features } \\
\text { Performance-only }\end{array}$ & $\begin{array}{c}\text { Customer Satisfaction } \\
\text { service satisfaction (both } \\
\end{array}$ \\
& technical and functional), & Survey \\
\hline
\end{tabular}


Table 2. The most popular scales and their individual items.

\begin{tabular}{ll}
\hline Scale & \\
\hline 1. & They should have up-to-date equipment \\
2. & Their physical facilities should be visually appealing \\
3. & Their employees should be well dressed and appear neat \\
4. & The appearance of the physical facilities of these firms should be in keeping with the type of services provided \\
& \\
5. & When these firms promise to do something by a certain time, they should do so \\
6. & When customers have problems, these firms should be sympathetic and reassuring \\
7. & These firms should be dependable \\
8. & They should provide their services at the time they promise to do so \\
9. & They should keep their records accurately
\end{tabular}

10. They shouldn't be expected to tell customers exactly when services should be performed (-)

11. It is not realistic for customers to expect prompt service from employees of these firms (-)

12. Their employees don't always have to be willing to help customers (-)

13. It is okay if they are too busy to respond to customer requests promptly (-)

\section{Assurance}

14. Customers should be able to trust employees of these firms

15. Customers should be able to feel safe in their transactions with these firms' employees

16. Their employees should be polite

17. Their employees should get adequate support from these firms to do their jobs well

\section{Empathy}

18. These firms should not be expected to give customers individual attention (-)

19. Employees of these firms cannot be expected to give customers personal attention (-)

20. It is unrealistic to expect employees to know what the needs of their customers are (-)

21. It is unrealistic to expect these firms to have their customers' best interests at heart (-)

22. They shouldn't be expected to have operating hours convenient to all their customers (-)

\section{Dimension 1 Physical Aspects}

\section{Appearance}

1. The store has modern-looking equipment and fixtures

2. The store and its physical facilities (trial rooms and restrooms) are visually attractive

3. Materials associated with this store's service (such as shopping bags, loyalty cards and catalogues) are visually appealing

4. The store has clean, attractive and convenient physical facilities (restrooms, fitting rooms)

\section{Convenience}

5. The store layout at this store makes it easier for customers to find what they need

6. The store layout at this store makes it easier for customers to move around in the store

\section{Dimension 2 Reliability}

\section{Promises}

7. When this store promises to do something (such as repairs, alterations) by a certain time, it will do so

8. This store provides its services at the time it promises to do so

9. This store performs the service right the first time

\section{Doing-it-Right}

10. This store has merchandise available when the customers want it

11. This store insists on error-free sales transactions and records

Dimension 3 Personal interaction 


\section{Inspiring Confidence}

12. Employees in the store have the knowledge to answer customers' questions

13. The behaviour of employees in this store instils confidence in customers

14. Customers feel safe in their transactions with this store

\section{Courteousness/Helpfulness}

15. The employees in this store give prompt service to customers

16. Employees in this store tell customers exactly when services will be performed

17. Employees in this store are never too busy to respond to customer's requests

18. This store gives customers individual attention

19. Employees in this store are consistently courteous with customers

20. Employees in this store treat customers courteously on the telephone. (deleted as not applicable in Indian context)

\section{Dimension 4 Problem Solving}

21. This store willingly handles returns and exchanges

22. When a customer has a problem, this store shows a sincere interest in solving it

23. Employees of this store are able to handle customer complaints directly and immediately

24. This store offers high quality merchandise

\section{Dimension 5 Policy}

25. This store provides plenty of convenient parking for customers

26. This store has operating hours convenient to all their customers

27. This store accepts all major credit cards

28. The store has its own credit card

\section{Customer Treatment}

1. Employees care for customers as they would like to be cared for

2. Employees go the "extra mile" for customers

3. We are noticeably more friendly and courteous than our competitors

4. Employees go out of their way to reduce inconveniences for customers

\section{Employee Empowerment}

5. Decisions are made "close to the customer." In other words, employees often make important customer decisions without seeking management approval

6. Employees have freedom and authority to act independently in order to provide excellent service

\section{Service Technology}

7. We enhance our service capabilities through the use of "state of the art" technology

8. Technology is used to build and develop higher levels of service quality

9. We use high levels of technology to support the efforts of men and women on the front line

\section{Service Failure Prevention}

10. We go out of our way to prevent customer problems

11. We go out of our way to "head off" or prevent customer problems rather than reacting to problems once they occur

12. We actively listen to our customers

\section{Service Failure Recovery}

13. We have an excellent customer complaint handling system for service follow-up

14. We have established problem-solving groups to enhance our ability to resolve service breakdowns

15. We provide follow-up service calls to confirm that our services are being provided properly

16. We provide every customer with an explicit service guarantee

\section{Service Standards Communication}

17. We do not wait for customers to complain, we use internal standards to pinpoint failures before we receive customer complaints

18. Every effort is made to explain the results of customer research to every employee in understandable terms 
19. Every employee understands all of the service standards that have been instituted by all departments

20. We have a developed chain of objectives linking together every branch in support of the corporate vision

21. Service performance measures are communicated openly with all employees regardless of position or function

\section{Service Vision}

22. There is a true commitment to service, not just lip service

23. Customers are viewed as opportunities to serve rather than as sources of revenue

24. It is believed that fundamentally, the organization exists to serve the needs of its customers

\section{Servant Leadership}

25. Management constantly communicates the importance of service

26. Management regularly spends time "in the field" or "on the floor" with customers and front-line employees

27. Management is constantly measuring service quality

SERV-OR

28. Management shows that they care about service by constantly giving of themselves

29. Management provides resources, not just "lip service" to enhance employee ability to provide excellent service

30. Managers give personal input and leadership into creating quality service

\section{Service Rewards}

31. Management provides excellent incentives and rewards at all levels for service quality, not just productivity

32. This organization noticeably celebrates excellent service

\section{Service Training}

33. Every employee receives personal skills training that enhances his/her ability to deliver high quality service

34. We spend much time and effort in simulated training activities that help us provide higher levels of service when actually encountering the customer

35. During training sessions we work through exercises to identify and improve attitudes toward customers

Parasuraman et al. (1985) built on Grönroos's idea, and formulated the five gaps model, which was the basis for a 22 -item questionnaire assessing quality in service, the SERVQUAL (Parasuraman et al., 1988) (see Table 2). The five most critical dimensions of quality were identified as reliability, responsiveness, assurance, empathy and tangibility. To a large extent this model and measure which has been critiqued and updated has dominated the field. The reason is probably because the five dimensions are clear and important and the test is short and the items interpretable in many settings.

Many instruments have been introduced for measuring service quality since. The best known alternative to SERVQUAL is SERVPERF, constructed by Cronin and Taylor (1992). Much discussion followed differentiating between the two models in order to conclude which one was more valid when predicting service quality.

A contrasting suggestion to Grönroos's (1982) original idea of comparing expectations with experience is the idea that the measurement of service quality should only include customer perceptions (Caro \& García, 2007).

Grönroos (1982) suggests that service quality is comprised of two dimensions, functional and technical. The functional dimension relates to how a service is delivered, where the technical dimension refers to an output of the service, e.g., what the customer receives. These aspects of service quality have been found to impact on customer attitudes towards a brand as well as on future behavioural intentions (Dagger \& Sweeney, 2006). This suggests that perception of service 
quality is determined by functional quality, technical quality and corporate image: that is the image and reputation of the organisation for service in general. Fonesca (2009) supported this model, proposing that these three factors represent the main determinants of satisfaction. Therefore, it is argued, service quality leads to satisfaction directly.

However, when measuring satisfaction, many challenges occur (Maričić, 2008). Satisfaction is a subjective measure of a customer's perception of the quality of a product or service. The measurement of satisfaction also encompasses expectations of quality of a product or service. Bateson (1995) highlights the difficulties of measuring service quality due to the fact of its intangibility, heterogeneity, inseparability and perishability.

Table 3 describes a number of service quality and customer satisfaction models and scales. Each scale is comprised of different dimensions. Some of these are consistent across models, such as reliability (SERVQUAL, RSQS, SERVPERF, Weighted SERV-PERF, SERVQUAL-R), suggesting this is a key dimension of customer satisfaction and service quality. The scales vary in the number of dimensions included, from $2-10$, varying in the different factors they think it is necessary to assess. Our research suggests that the SERVQUAL and the weighted SERV-PERF are the most used, however it is only possible to assess the published research in the area, and it may be that many of the other scales are widely employed throughout business yet not published in either the academic or trade literature.

These scales have not all been subjected to exacting and repeated psychometric assessment such as checking their dimensions through exploratory and confirmatory factor analysis, as well as the internal reliability (Cronbach's Alpha) of those dimensions. More importantly perhaps in this area, there are few good norms so that those who use the measures can compare their data to that of a large group of representative service providers.

\section{Discussion}

There are various ways to evaluate the different scales mentioned in the table. The can be divided into psychometric and practical criteria. Psychometricians are interested in such things as reliability, validity and dimensionality. They look for evidence that the various scale items factor or cluster into the various dimensions the authors proposed. They are also interested in the internal reliability of the questionnaire, but most of all the validity: that is the proof that the questionnaire data predicts actual behaviour like sales. Some scales have been put to the test while others have received much less attention. Whilst it is relatively cheap and easy to develop a model and questionnaire items it is much more expensive in terms of time and money to psychometrically evaluate the scale.

Table 3 shows that where measured the tests seem to have acceptable levels of internal reliability, though there is less work on test-retest reliability. Psychometricians would in this case be very interested in the factor structure of these measures using factor analysis and structural equation modelling to try to 
Table 3. Research on these scales.

\begin{tabular}{|c|c|c|c|c|}
\hline Scale Name & Authors & Dimensions & Psychometric Properties & Evidence it is used \\
\hline & & & $\begin{array}{l}\text { The findings show that the } \\
\text { SERVQUAL scale exhibits } \\
\text { both reliability and } \\
\text { convergent and divergent } \\
\text { validity when } \\
\text { measuring classroom } \\
\text { service quality; in fact, in } \\
\text { these regards, it } \\
\text { outperforms traditional } \\
\text { student assessment scales } \\
\text { (Stodnick \& Rogers, 2008). }\end{array}$ & $\begin{array}{l}\text { Adapted to be used across a } \\
\text { range of Scottish council } \\
\text { services (Wisniewski, 2001). } \\
\text { A particular electric } \\
\text { company (SCECO-East } \\
\text { utilizes SERVQUAL for } \\
\text { measuring customers' } \\
\text { perceptions of service quality } \\
\text { (Jannadi \& Al-Saggaf, 2000). }\end{array}$ \\
\hline $\begin{array}{l}\text { Service Quality } \\
\text { (SERVQUAL) }\end{array}$ & $\begin{array}{c}\text { Parasuraman et } \\
\text { al. (1985) }\end{array}$ & $\begin{array}{ll}\text { 1. } & \text { Tangibles } \\
\text { 2. } & \text { Reliability } \\
\text { 3. } & \text { Responsiveness } \\
\text { 4. } & \text { Assurance } \\
\text { 5. Empathy }\end{array}$ & $\begin{array}{l}\text { First, the reliability of the scale } \\
\text { ( } \mathrm{A} \geq 0.95 \text { ) and of its constituent } \\
\text { dimensions (all } \mathrm{A} \geq 0.71 \text { ) is } \\
\text { adequate, which confirms their } \\
\text { internal consistency. Second, the } \\
\text { existence of five dimensions (i.e., } \\
\text { tangible elements, reliability, } \\
\text { responsiveness, assurance, and } \\
\text { empathy) as they were originally } \\
\text { suggested was confirmed. Third, } \\
\text { the reliability dimension has the } \\
\text { highest weighting in importance } \\
\text { as well as a positive and } \\
\text { significant relationship with } \\
\text { overall quality. It is concluded } \\
\text { that the SERVQUAL scale } \\
\text { adapted to the services } \\
\text { performed by travel agencies } \\
\text { constitutes a valid and reliable } \\
\text { instrument for measuring } \\
\text { service quality. }\end{array}$ & $\begin{array}{l}\text { This instrument has been } \\
\text { widely adopted for the } \\
\text { measurement of service } \\
\text { quality (i.e. Babakus \& } \\
\text { Mangold, 1992; Heskett, } \\
\text { Sasser, \& } \\
\text { Schlesinger, 1997; Reichheld, } \\
\text { 1996). According to } \\
\text { Parasuraman, Zeithaml and } \\
\text { Berry (1993), its major } \\
\text { advantage over the } \\
\text { alternatives is its diagnostic } \\
\text { power and thus its practical } \\
\text { application, as direct } \\
\text { measures, such as } \\
\text { SERVPERF and weighted } \\
\text { SERVPERF, tend to magnify } \\
\text { customers' assessments } \\
\text { (Andronikidis \& Bellou, } \\
\text { 2010). }\end{array}$ \\
\hline $\begin{array}{l}\text { Retail Service Quality } \\
\text { Scale (RSQS) }\end{array}$ & $\begin{array}{l}\text { Dabholkar } \\
\text { Thorpe \& Rentz } \\
\quad \text { (1996) }\end{array}$ & $\begin{array}{ll}\text { 1. } & \text { Physical Aspects } \\
\text { 2. } & \text { Reliability } \\
\text { 3. Personal Interaction } \\
\text { 4. Problem Solving } \\
\text { 5. Policy }\end{array}$ & $\begin{array}{l}\text { The retail service quality scaleis a } \\
\text { reliable instrument, returning an } \\
\text { overall Cronbach alpha of } 0.78 . \\
\text { Taking } 0.7 \text { and above as } \\
\text { indicator of reliability (Nunnally, } \\
\text { 1978), we see that all underlying } \\
\text { sub-dimensions/dimensions are } \\
\text { reliable except the } \\
\text { Convenience sub-dimension } \\
\text { pertaining to Physical } \\
\text { aspects dimension of service } \\
\text { quality (alpha = 0.67). } \\
\text { This compares to the } \\
\text { findings of Boshoff and } \\
\text { Terblanche (1997) who } \\
\text { found the RSQS scale } \\
\text { (alpha = 0.93) and all } \\
\text { dimensions reliable except } \\
\text { the Policy dimension } \\
\text { (alpha = 0.68). Kaul (2005). }\end{array}$ & $\begin{array}{l}\text { Kim \& Byoungho (2002) } \\
\text { report the RSQS a useful } \\
\text { scale for measuring service } \\
\text { quality of discount stores } \\
\text { across two different cultural } \\
\text { contexts of the US \& South } \\
\text { Korea. } \\
\text { Boshoff \& Terblanche (1997) } \\
\text { report highly encouraging } \\
\text { results for the RSQS } \\
\text { applicability in the context } \\
\text { of department stores, } \\
\text { speciality stores and } \\
\text { hypermarkets in } \\
\text { South Africa. }\end{array}$ \\
\hline
\end{tabular}




SERVPERF
(the performance
component of the
Service Quality scale
(SERVQUAL)

(SERVQUAL)

$\begin{array}{cll} & \text { 1. } & \text { Tangibles } \\ \text { Zarasuraman, } & \text { 2. } & \text { Reliability } \\ \text { Berry (1985, } & \text { 3. } & \text { Responsiveness } \\ \text { 1988) } & \text { 4. } & \text { Assurance } \\ & \text { 5. } & \text { Empathy }\end{array}$

SERVPERF

(performance-only)

results in more reliable estimations, greater convergent and discriminant validity, greater explained

variance, and consequently less bias than the SERVQUAL scale (Cronin and Taylor, 1992; Parasuraman et al., 1994; Quester, Wilkinson, \& Romaniuk, 1995; Llusar and Zornoza, 2000).
This study applies SERVPERF items to urban community development issues by considering the utility of the SERVPERF items in predicting a propensity to shop neighbourhood stores as compared to a propensity to shop in areas outside the neighborhood (Marshall \& Smith, 2000).

This study compares all four alternatives (SERVQUAL, SERVPERF, weighted SERVQUAL, weighted SERVPERF) within the auto-repair industry in

Greece. Based on data from 1043 customers, overall results are in line with previous studies, confirming the multidimensionality of the service-quality construct and the five-factor

1. Tangibles

Cronin \&

2. Reliability

3. Responsiveness

4. Assurance

5. Empathy

SERVPERF pattern. In disagreement with previous studies, findings show that the importance-weighted SERVPERF scale provides the greatest diagnostic information

(Andronikidis \& Bellou, 2010).

In this paper, a weighted SERVPERF model was expressed to assess taxi service quality of Hangzhou, China (Yao \& Ding, 2011).

The ACSI \& ECSI have been extensively applied (Fornell et al., 1996; Anderson and Fornell, 2000; Martensen,

American Customer Satisfaction Indexes

(ACSI)/European

Fornell (1992)

E-CSI:

Customer Satisfaction

Indexes (ECSI)

Grønholdt, \& Kristensen, 2000; Dermanov and Eklof, 2001; Fornell, 2001; Eklof and Westlund, 2002; Yeung, Chew-Ging, \& Ennew, 2002). 


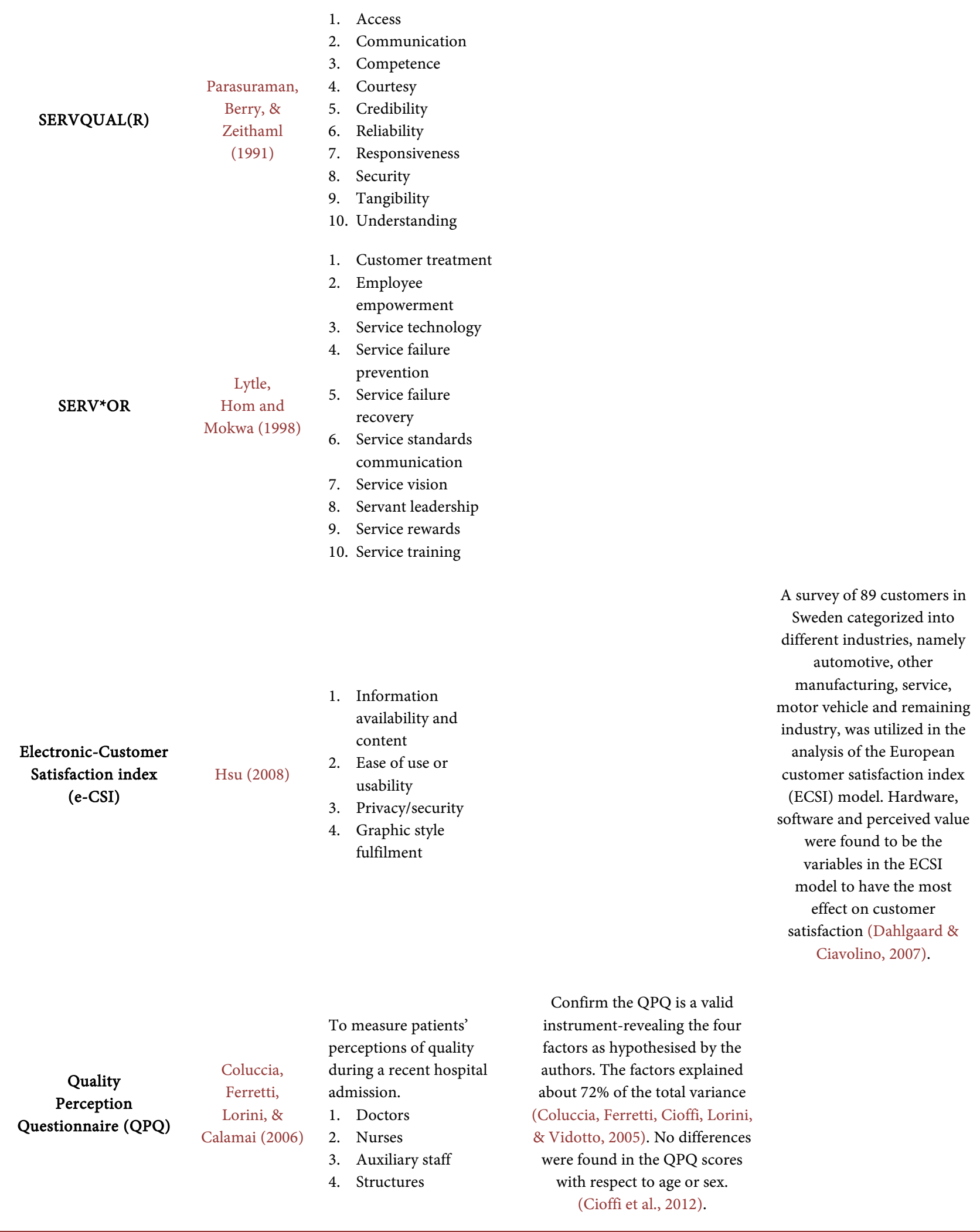

determine if there is a universal structure to the dimensions people use in the evaluation of services. So far there appears very little research of that kind. More 
importantly there appears no research to indicate which of the various scales in these measures relates most powerfully to the overall satisfaction of the customer

Further there is little evidence that the scales retain their properties when translated into different languages. Similarly, it would be of interest to examine demographic correlates of these scales to attempt to determine whether, for instance age, social class or gender were related to the different factors in customer evaluation.

There can be no validity without reliability but it appears that there is relatively little published evidence on the validity of these scales. This research is not easy and usually involves correlation customer service data and other salient data like sales, profit, store visits or repeat purchases over time to assess the expected relationship between these measures. More interesting is how much variance is accounted for by the customer service data compared to other issues, like price which may attract customers. This could answer the question of whether it is indeed a wise investment to spend money on attempts to improve customer service.

The second and not always closely related criterion is always practical. Table 3 shows some evidence of the applications of these scales. Practitioners want questions which are very short clear and easy for customers to complete and yet measure the dimensions they are really interested in. They are often happy to trade off length for psychometric reliability and add as well as remove items they think not relevant to them.

They also like to use the same measure for different purposes. Some are concerned that you may annoy customers by using such measures while other believe the opposite, namely that customers feel appreciative in being asked. Most seem to be used in the hospitality industries but that is changing.

There are inevitable gaps in Table 2 and Table 3 . There may well be other measures that are in use and many other papers that attempt to assess these instruments. In that sense these tables are, and will always be preliminary, but as far as we know no one has attempted a review such as this.

\section{Conclusion}

Both those in pure and applied research want scales that are short, psychometrically sound and sensitive to the various facets/dimensions that make up the behaviour (customer service) that is assessed. The review has located what we believe are the most well known and used measures and the evidence for them. We hope to be able to update this report every so often as the literature and the use of these measures increases.

\section{References}

Anderson, E. W., \& Fornell, C. (2000). Foundations of the American Customer Satisfaction Index. Total Quality Management, 11, 869-883.

https://doi.org/10.1080/09544120050135425

Andronikidis, A. I., \& Bellou, V. (2010). Verifying Alternative Measures of the Service 
Quality Construct: Consistencies and Contradictions. Journal of Marketing Management, 26, 5-6. https://doi.org/10.1080/02672570903498850

Babakus, E., \& Mangold, G. (1992). Adapting the SERVQUAL Scale to Hospital Services: An Empirical Investigation. Health Service Research, 26, 767-780.

Bateson (1995). SERVQUAL: Review, Critique, Research Agenda. European Journal of Marketing, 30, 8-32.

Boshoff, C., \& Terblanche, N. (1997). Measuring Retail Service Quality: A Replication Study. South African Journal of Business Management, 28, 123-128.

Caro, L. M., \& Garcia, J. A. M. (2007). Measuring Perceived Service Quality in Urgent Transport Service. Journal of Retailing and Consumer Services, 14, 60-72. https://doi.org/10.1016/j.jretconser.2006.04.001

Cioffi, R., Coluccia, A., Ferretti, F., Lorini, F., Saggino, A., \& Furnham, A. (2012). A Psychometric Study of Quality Perception Questionnaire. Swiss Journal of Psychology, 71, 101-106. https://doi.org/10.1024/1421-0185/a000076

Coluccia, A., Cioffi, R., Ferrentti, F., Lorini, F., \& Vidotto, G. (2006). Questionnaire of Perceived Quality (QQP): A Study on the Differences of Gender. Italian Journal of Occupational Medicine and Ergonomics, 28, 53-60.

Coluccia, A., Ferretti, F., Cioffi, R., Lorini, F., \& Vidotto, G. (2005). Quality Perception and Customer Satisfaction: A Study on the QPQ. Italian Journal of Forensic Medicine, 27, 303-319.

Cronin, J. J., \& Taylor, A. S. (1992). Measuring Service Quality: A Reexamination and an Extension. Journal of Marketing, 56, 55-67. https://doi.org/10.2307/1252296

Dabholkar, P. A., Thorpe, D. I., \& Rentz, J. O. (1996). A Measure of Service Quality for Retail Stores: Scale Development and Validation. Journal of the Academy of Marketing Science, 24, 3-16. https://doi.org/10.1007/BF02893933

Dagger, T. C., \& Sweeney, J. C. (2006). The Effect of Service Evaluations on Behavioural Intentions and Quality of Life. Journal of Service Research, 9, 3-18. https://doi.org/10.1177/1094670506289528

Dahlgaard, J. J., \& Ciavolino, E. (2000). Analysing Management Factors of Enterprise Performance. Asian Journal on Quality, 3, 1-10.

Dermanov, V., \& Eklof, J. (2001). Using Aggregate Customer Satisfaction Index: Challenges and Problems of Comparisons with Specific Reference to Russia. Total Quality Management, 12, 1054-1063.

Eklof, J., \& Westlund, A. (2002). The Pan-European Customer Satisfaction Index Programme-Current Work and the Way Ahead. Total Quality Management, 11, 10991106. https://doi.org/10.1080/09544120200000005

Fonesca, J. (2009). Customer Satisfaction Study via a Latent Segment Model. Journal of Retailing and Consumer Services, 16, 352-359. https://doi.org/10.1016/j.jretconser.2009.04.001

Fornell, C. (1992). A National Customer Satisfaction Barometer: The Swedish Experience. Journal of Marketing, 56, 6-21. https://doi.org/10.2307/1252129

Fornell, C. (2001). The Score of Satisfaction. Harvard Business Review, 79, 120-121.

Fornell, C., Johnson, M., Anderson, E., Cha, J., \& Bryant, B. (1996). The American Customer Satisfaction Index: Nature, Purpose and Findings. Journal of Marketing, 60, 718. https://doi.org/10.2307/1251898

Garvin, D. (1984). Product Quality: An Important Strategic Weapon. Business Horizons, 27, 40-43. https://doi.org/10.1016/0007-6813(84)90024-7

Gitomer, J. (1998). Customer Satisfaction Is Worthless, Customer Loyalty Is Priceless: 
How to Make Customers Love You, Keep Them Coming Back, and Tell Everyone They Know. Austin, TX: Bard Press.

Grönroos, C. (1982). Strategic Management and Marketing in the Service Sector. London: Chartwell-Bratt.

Heskett, J. L., Sasser, W. E. J., \& Schlesinger, L. A. (1997). The Service Profit Chain. New York, NY: Free Press.

Hsu, S.-H. (2008). Developing an Index for Online Customer Satisfaction: Adaptation of American Customer Satisfaction Index. Expert Systems with Applications, 34, 30333042. https://doi.org/10.1016/j.eswa.2007.06.036

Jannadi, O. A., \& Al-Saggaf, H. (2000). Measurement of Quality in Saudi Arabian Service Industry. International Journal of Quality \& Reliability Management, 17, 949-966. https://doi.org/10.1108/02656710010353867

Kaul, S. (2005). Measuring Retail Service Quality: Examining Applicability of International Research Perspectives in India (Working Paper 2005-10-02). Ahmedabad: Indian Institute of Management.

Keiningham, T. L., \& Vavra, T. G. (2001). The Customer Delight Principle: Exceeding Customers' Expectations for Bottom-Line Success. Chicago, IL: McGraw-Hill.

Kim, S., \& Byoungho, J. (2002). Validating the Retail Service Quality Scale for US and Korean Customers of Discount Stores: An Exploratory Study. Journal of Services Marketing, 7, 223-237. https://doi.org/10.1108/08876040210427218

Llusar, J. C. B., \& Zornoza, C. C. (2000). Validity and Reliability in Perceived Quality Measurement Models: An Empirical Investigation in Spanish Ceramic Companies. International Journal of Quality \& Reliability Management, 17, 899-918. https://doi.org/10.1108/02656710010325237

Lytle, R., Hom, P., \& Mokwa, M. (1998). SERV OR: A Managerial Measure of Organizational Service-Orientation. Journal of Retailing, 74, 455-489.

https://doi.org/10.1016/S0022-4359(99)80104-3

Maričić, B. (2008). Ponašanjepotrošača. Belgrade: CID.

Marshall, K., \& Smith, J. (2000). SERVPERF Utility for Predicting Neighborhood Shopping Behavior. Journal of Nonprofit and Public Sector Marketing, 7, 45-57. https://doi.org/10.1300/J054v07n04_05

Martensen, A., Grønholdt, L., \&Kristensen, K. (2000). The Drivers of Customer Satisfaction and Loyalty: Cross-Industry Finding from Denmark. Total Quality Management, 11, 544-553. https://doi.org/10.1080/09544120050007878

McColl-Kennedy, J., \& Schneider, U. (2000). Measuring Customer Satisfaction: Why, What and How? Total Quality Management, 11, 883-889. https://doi.org/10.1080/09544120050135434

Nunnally, J. C. (1978). Psychometric Theory. New York, NY: McGraw Hill.

Parasuraman, A., Berry, L. L., \& Zeithaml, V. A. (1991). Refinement and Reassessment of SERVQUAL Scale. Journal of Retailing, 67, 420-450.

Parasuraman, A., Zeithaml, V. A., \& Berry, L. L. (1985). A Conceptual Model of Service Quality and Its Implications for Future Research. Journal of Marketing, 49, 41-50. https://doi.org/10.2307/1251430

Parasuraman, A., Zeithaml, V. A., \& Berry, L. L. (1988). SERVQUAL: A Multiple-Item Scale for Measuring Consumer Perception of Service Quality. Journal of Retailing, 64, $12-40$.

Parasuraman, A., Zeithaml, V. A., \& Berry, L. L. (1993). Research Note: More on Improving Service Quality Measurement. Journal of Retailing, 69, 140-147. 
https://doi.org/10.1016/S0022-4359(05)80007-7

Parasuraman, A., Zeithaml, V. A., \& Berry, L. L. (1994). Reassessment of Expectations as a Comparison Standard in Measuring Service Quality: Implications for Future Research. Journal of Marketing, 58, 111-124. https://doi.org/10.2307/1252255

Quester, P., Wilkinson, J. W., \& Romaniuk, S. (1995). A Test of Four Service Quality Measurement Scales: The Case of the Australian Advertising Industry. Working Paper 39, Nantes: Centre de Recherche Et D'études Appliquées, Group esc Nantes Atlantique, Graduate School of Management.

Reichheld, E. E. (1996). The Loyalty Effect. Boston, MA: Harvard Business School Press.

Senić, R., \& Senić, V. (2008). Menadžment I marketing usluga. Prizma: Kragujevac, Serbia.

Seth, N., Deshmunkh, S. G., \&Vrat, P. (2005). Service Quality Models: A Review. International Journal of Quality and Reliability Management, 22, 913-949. https://doi.org/10.1108/02656710510625211

Stodnick, M., \& Rogers, P. (2008). Using SERVQUAL to Measure the Quality of the Classroom Experience. Journal of Innovative Education, 6, 115-133. https://doi.org/10.1111/j.1540-4609.2007.00162.x

Vázquez et al. (2001). Expectations a Comparison Standard in Measuring Service Quality: An Assessment of a Reassessment. Journal of Marketing, 58, 132-139.

Wisniewski, M. (2001). Using SERVQUAL to Assess Customer Satisfaction with Public Sector Services. Managing Service Quality: An International Journal, 11, 380-388. https://doi.org/10.1108/EUM0000000006279

Yao, Z.-G., \& Ding, X.-D. (2011). Measuring Passenger's Perceptions of Taxi Service Quality with Weighted SERVPERF: A Case of Hangzhou, China. Applied Mechanics and Materials, 97-98, 1181-1184.

https://doi.org/10.4028/www.scientific.net/amm.97-98.1181

Yeung, M., Chew-Ging, L., \& Ennew, C. (2002). Customer Satisfaction and Profitability: A Reappraisal of the Nature of the Relationship. Journal of Targeting, Measurement, Analysis and Marketing, 11, 24-31. https://doi.org/10.1057/palgrave.jt.5740064

\section{Submit or recommend next manuscript to SCIRP and we will provide best service for you:}

Accepting pre-submission inquiries through Email, Facebook, LinkedIn, Twitter, etc. A wide selection of journals (inclusive of 9 subjects, more than 200 journals)

Providing 24-hour high-quality service

User-friendly online submission system

Fair and swift peer-review system

Efficient typesetting and proofreading procedure

Display of the result of downloads and visits, as well as the number of cited articles

Maximum dissemination of your research work

Submit your manuscript at: http://papersubmission.scirp.org/

Or contact psych@scirp.org 